SUSTAINABLE FORESTRY

COLLECTION 81-82, 2020
ODRŽIVO ŠUMARSTVO

ZBORNIK RADOVA 81-82, 2020

UDK $630 * 434(497.11$ Vidlič $)=111$

UDK $630 * 231.322+630 * 43(497,11$ Vidlič $)=111$

Original scientific paper

\title{
PHYTOCOENOLOGICAL CHARACTERISTICS OF BEECH FORESTS AT LOCALITY VISOKA STENA THE THIRD YEAR AFTER THE WILDFIRE ON VIDLIČ MOUNTAIN
}

\author{
Ljubinko RAKONJAC ${ }^{1}$, Marija MARKOVIĆ ${ }^{2}$, Biljana NIKOLIĆl, \\ Aleksandar LUĆIĆ ${ }^{I}$, Tatjana RATKNIĆ
}

\begin{abstract}
In this paper, the influence of wildfire on beech forests the third year after the fire at locality Visoka Stena on the Vidlic Mountain is followed. The results of field studies are presented in the form of phytocoenological table. The quantitative increase in the number of species diversity index in comparison to the previous two seasons was registered. Increasing number of woody and shrubby representatives of plants influences more favorable conditions for survival, germination, and further development of beech saplings in their shadows, which, with a greater wealth of nutrients in the soil than before the fire, are the good prerequisites for gradual natural regeneration of beech forests.
\end{abstract}

Keywords: wildfire, beech forest, diversity

\footnotetext{
${ }^{I}$ PhD Ljubinko RAKONJAC, Principal Research Fellow, PhD Biljana NIKOLIĆ, Principal Research Fellow, PhD Aleksandar LUČĆĆ, Senior Research Associate, PhD Tatjana RATKNIĆ, Research Associate, Institute of Forestry, Belgrade;

${ }^{2}$ PhD Marija MARKOVIĆ, Senior Research Associate, Faculty of Sciences and Mathematics, University of Niš Corresponding author: Marija Marković, Višegradska 33, 18000 Niš, tel: +381 18533015, email: marijam@pmf.ni.ac.rs
}

Acknowledgment: This paper was realized as a part of the project 'The development of technological processes in forestry in order to realize the optimal forest cover '(200027), financed by the Ministry of Education and Science of the Republic of Serbia 


\section{FITOCENOLOŠKE KARAKTERISTIKE BUKOVIH ŠUMA NA LOKALITETU VISOKA STENA TREĆE GODINE POSLE POŽARA NA PLANINI VIDLIČ}

Izvod: U radu je prikazan uticaj požara na bukove šume na lokalitetu Visoka stena na planini Vidlič treće godine posle požara. Rezultati terenskih istraživanja su prikazani u vidu fitocenološke tabele. Zabeleženo je kvantitativno povećanje indeksa diverziteta u odnosu na prethodne dve sezone. Povećanje broja drvenastih $i$ žbunastih predstavnika dovodi do povoljnijih uslova za klijanje, opstanak $i$ dalji razvoj bukovog podmladka u njihovoj senci što, uz veće bogatstvo hranljivih materija u zemljištu nego pre požara, predstavljaju dobre preduslove za postepeno obnavljanje bukovih šuma prirodnim putem.

Ključne reči: požar, bukova šuma, diverzitet

\section{INTRODUCTION}

Frequent droughts, dry and hot summers, and sometimes even autumns with the slightest human negligence led to large fires in nature. The intensity and duration of a fire are the two most important components in assessing its severity, which affects the magnitude of the damage, that it causes (Certini, G., 2005). The fire destroys the vegetation, and on the other hand, it affects the formation of new ecological conditions.

The area of our country is a climatogenic forest area. Therefore, forest fires in our literature are given a great importance. Forest fires can cause enormous consequences and devasting impact on forest ecosystems. For short period of time forest fires can burn large forest mass and make the forest ecosystem an erasure. Even so, the forest vegetation has a very important and essential ability. It is capacity for natural regeneration. The forest ecosystem can be revitalized and naturally restored even after the catastrophic effects of fire (Velkovski, N. et al., 2012). After the layer of ash on the soil surface is formed, almost a year after fire, habitat revitalization occurs, which continues through a series of successive stages, starting from initial formations up to the more stable phytocenoses (Vukićević, E., 1965). Each succesional stage of vegetation is characterized by certain floristic composition and environmental conditions, while late subsequent communities are usually les dynamic and more stable (Marković, S.M. et al., 2018a).

Beech is a mesophilic species. In the beech forests, the floor of herbaceous layer is poorly developed, the moisture content is high, and there is no combustible material such as resin and explosively burning conifers. Due to these facts, some authors on a scale of 1 to 5 for beech, as well as for other mesophilic species of deciduous trees, state that they have the weakest flammability and classify it in the 5th category in the classification of fire hazards (Ratknić, M. et al., 2006). However, although beech is a mesophilic species, it is a tree with a thin bark, and we can classify it among the species sensitive to fire, which is confirmed by some other authors (Dimitrov, according to Petrović, N., 1965). 
The forest fires are related to the current climatic conditions (air and soil temperature, humidity in the habitat, wind direction and speed of wind), forest structure (age and types of trees, number of layers, layers density), and the character of the substrate. The danger of wildfire depends mostly on the humidity of the forest soil, but also on the air temperature. The wind affects the occurrence of fire in two ways: on the one hand it dries out the moisture in the soil and the burning material, and on the other hand it helps the spread and speed of the fire (Kamilovski, M., 1965). According to Petrović, N. (1956), beech forests in the eastern part of Serbia are susceptible to frequent east and southeast winds, which can affect the occurrence and spread of fires.

According to Nikolov, N. (2015) between 2004 and 2013, 3800 ha, of which 2250 ha categorized as forests, were destroyed by wildfires in Serbia. In the period of 2003 - 2007 year, 580 wildfires were counted and most of them (370) were in 2007 (Tabaković-Tošić, M. et al., 2009). The fire on Vidlič Mountain happened in the summer 2007 and burned over 1000 ha of forest area, that was impacted by uncontrolled wildfire (Panić, M., 2007). The vegetation dynamic of burned xeric grasslands and rocky grounds in three consecutive seasons (20082010) was followed, and a comparison between the stages of vegetation established at the burned sites with the vegetation of similar, unburned habitats was carried out (Marković, S.M. et al., 2018a). Floristic composition of oak forests and oriental hornbeam scrubs in the first three years after a wildfire was done by Rakonjac, $\mathrm{Lj}$. et al. (2018). Phytocoenological study of vegetation of beech forest at locality Visoka stena the first year after fire was carried out by Marković, M. et al. (2018b), and the second year by Rakonjac, Lj. et al. (2020). The aim of this paper is to consider the phytocoenological changes during the third year after the fire at the locality Visoka stena on the Vidlič Mountain. The stages of natural gradual recovery of beech forest vegetation, which was affected by the fire, can be established, by comparing the floristic composition of the analyzed stands from year to year after the fire.

\section{MATERIAL AND METHODS}

The field research of the areas of beech forest affected by the fire on Mt. Vidlič were conducted in 2010. The identification of the collected plant material was performed according to Josifović, M. (1970-1986), and the nomenclature was adjusted in accordance with Flora Europaea (Tutin, T.G. et al., 1964-1980; Tutin, T.G. et al., 1993). The plant material collected during the field research was deposited in the Herbarium of the Department of Biology and Ecology, Faculty of Sciences and Mathematics, University of Niš: Herbarium Moesiacum (HMN).

The results of the phytocoenological studies of dry pastures and rocky grounds affected by the fire performed on the field using the method of BraunBlanquet, J. (1964) were presented in the form of phytocoenological table. Eight relevés on the stands a-h were sampled. Alpha diversity of species in the community, within the minimum range, was performed in the software package of the "Flora" program (Karadžić, B., et al., 1998).

The results of the study of the floristic composition of beech forest the third year after the wildfire at the same locality were compared with the already 
published results relating to the first and second year after the wildfire (Marković, M. et al., 2018b; Rakonjac, Lj. et al. 2020).

\section{RESULTS AND DUSCISSIONS}

Relevés of beech forest affected by the fire at locality Visoka stena on Vidlič Mountain have been sampled at altitudes of 1035 to $1370 \mathrm{~m}$, with exposures: W, NW, $\mathrm{N}$ and NE, terrain inclination 5 to $70^{\circ}$ (Table 1), with number of species from 29 to 69 and the value of Simpson's diversity index ranging from 0.959 to 0.983 . The total of 168 species and subspecies were recorded in the stands a-i which indicates great diversity.

Table 1. Beech forests at locality Visoka stena the third year after fire on the Vidlič Mountain (2010)

\begin{tabular}{|c|c|c|c|c|c|c|c|c|c|}
\hline Altitude (m) & 1035 & 1150 & 1170 & 1140 & 1135 & 1130 & 1050 & 1050 & $\mathrm{D}$ \\
\hline Exposure & W & NW & $\mathrm{N}$ & NW & $\mathrm{N}$ & NE & NW & NW & $\mathrm{e}$ \\
\hline Terrain inclination $\left({ }^{\circ}\right)$ & $70^{\circ}$ & $5^{\circ}$ & $60^{\circ}$ & $20^{\circ}$ & $30^{\circ}$ & $60^{\circ}$ & $40^{\circ}$ & $30^{\circ}$ & $\mathrm{g}$ \\
\hline Relevé area (m) & $10 \times 10$ & $10 \times 10$ & $10 \times 10$ & $3 \times 3$ & $10 \times 10$ & $10 \times 10$ & $5 \times 10$ & $10 \times 10$ & $\mathrm{r}$ \\
\hline $\begin{array}{l}\text { General vegetation } \\
\text { coverage }(\%)\end{array}$ & 80 & 80 & 60 & 80 & 90 & 70 & 80 & 65 & $\mathrm{e}$ \\
\hline Vegetation height (m) & 2,5 & 6,5 & 1,5 & 1 & 1,5 & 0,8 & 1,5 & 2 & o \\
\hline Relevé number & $\mathbf{a}$ & b & c & d & $\mathbf{e}$ & f & g & $\mathbf{h}$ & $\mathrm{f}$ \\
\hline Floristic composition: & & & & & & & & & $\mathrm{p}$ \\
\hline Threes layer: & & & & & & & & & r. \\
\hline Salix caprea $\mathrm{L}$. & . & . & . & . & . & . & . & +.1 & I \\
\hline Populus tremula $\mathrm{L}$. & . & . & . & . & . & . & . & +.1 & I \\
\hline $\begin{array}{l}\text { Fagus moesiaca (K. } \\
\text { Maly) Czecz. }\end{array}$ & . & 2.2 & · & . & $\cdot$ & · & · & $\cdot$ & I \\
\hline \multicolumn{10}{|l|}{ Schrub layer: } \\
\hline Rubus idaeus L. & . & +.1 & 1.2 & +.2 & +.1 & +.1 & +.1 & +.1 & $\mathrm{~V}$ \\
\hline Acer campestre $\mathrm{L}$. & . & 1.1 & +.1 & +.1 & +.2 & . & +.1 & +.1 & IV \\
\hline Salix caprea $\mathrm{L}$. & +.1 & +.1 & . & +.1 & . & +.1 & . & +.2 & IV \\
\hline Corylus avellana $\mathrm{L}$. & +.1 & . & 1.1 & +.1 & . & +.1 & +.1 & . & IV \\
\hline $\begin{array}{l}\text { Chamaecytisus ciliatus } \\
\text { (Wahlenb.) Rothm. }\end{array}$ & +.1 & . & +.1 & . & . & +.1 & +.1 & +.1 & IV \\
\hline $\begin{array}{l}\text { Sorbus aria }(\mathrm{L} .) \\
\text { Crantz. }\end{array}$ & +.1 & . & . & +.1 & +.1 & +.1 & +.1 & . & IV \\
\hline $\begin{array}{l}\text { Spiraea } \\
\text { chamaedryfolia } \mathrm{L} .\end{array}$ & . & +.1 & 3.3 & . & +.1 & 2.2 & 3.3 & . & IV \\
\hline Clematis vitalba $\mathrm{L}$. & +.1 & . & +.1 & - & . & . & +.1 & +.1 & III \\
\hline Sambucus ebulus L. & . & +.1 & +.1 & . & +.1 & . & . & +.1 & III \\
\hline $\begin{array}{l}\text { Sorbus torminalis (L.) } \\
\text { Crantz }\end{array}$ & +.1 & +.1 & . & +.1 & . & . & . & . & II \\
\hline Populus tremula $\mathrm{L}$. & $\cdot$ & +.1 & . & $\cdot$ & +.1 & +.1 & . & . & II \\
\hline Crataegus monogyna & +.1 & +.1 & . & . & . & . & . & . & II \\
\hline
\end{tabular}


Jacq.

Lonicera xylosteum L.

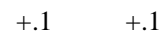

Chamaecytisus

elongatus (L.) Link.

Rosa canina L.

Rosa rubiginosa L.

Rosa pimpinellifolia L.

Sambucus racemosa L.

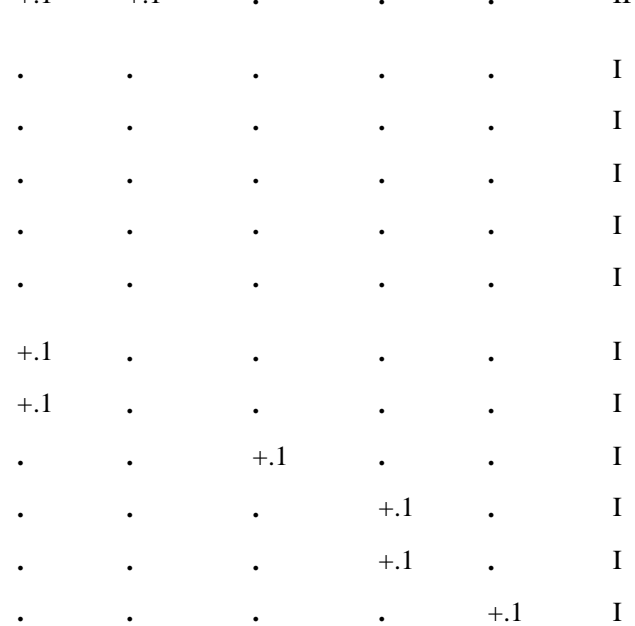

Cotoneaster

integerrimus Medicus

Rosa arvensis Hudson

Daphne mezereum L.

Sorbus aucuparia L.

Acer pseudoplatanus L.

Fraxinus ornus L.

\section{Herbaceous layer:}

Galium mollugo L.

Doronicum columnae

Ten.

Sedum album L.

Vicia cracca L.

Lamium maculatum L.

Coronilla varia $\mathrm{L}$.

Epilobium

angustifolium $L$.

Leucanthemum vulgare

Lam.

Poa angustifolia L.

Moehringia muscosa L.

Mycelis muralis (L.)

Dumort.

Lilium martagon L.

Lathyrus pratensis L.

Knautia drymeia

Heuffel

$$
\begin{array}{lll}
1.1 & +.1 & +.1
\end{array}
$$

$1.1+.1$

$+.1$

V

$\begin{array}{llllll}+.1 & +.2 & + & +1 & +.1 & +.1\end{array}$$$
\text { . }
$$$$
+1
$$$$
1.1+.1
$$$$
+.1 \quad 1.1
$$$$
+.1
$$$$
+.1
$$

$$
\text { - }
$$$$
+.1
$$$$
1.2
$$$$
+.1
$$$$
+.1
$$$$
+.1
$$$$
3.3
$$$$
\text { IV }
$$

$$
+.1
$$$$
\text { - IV }
$$

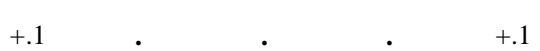

1.3

$+.3$

III

$+.1$

$+.2+.1$

IV

1.1

$\cdot$
+.1
$\cdot$
+.1

$+.1+.1$

IV

$+.1$

$$
+
$$$$
\begin{array}{ll}
+.1 \quad 2.2
\end{array}
$$

1.2

macrorrhizum L.

$+.2$

Veronica chamaedrys

L.

$+.2$

Medicago lupulina $\mathrm{L}$

$+.2$

Helianthemum

nummularium (L.)

Miller

Fragaria viridis

Duchesne

Hieracium murorum $\mathrm{L}$.

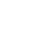

$\begin{array}{llll}\cdot & +.2 & +.1 & \text { III } \\ +.1 & +.1 & \cdot & \text { III } \\ 2.2 & 1.1 & +.2 & \text { III } \\ 1.2 & 1.1 & +.1 & \text { III } \\ +.1 & +.1 & +.1 & \text { III } \\ +.1 & . & \cdot & \text { III }\end{array}$


Poa nemoralis L.

Taraxacum officinale

Weber

$+.1+1$

$+.1$

$+.1$

III

Saxifraga tridactylites

L.

$+.1 \quad+.2$

$+.1+.1$

III

Trifolium pratense $\mathrm{L}$.

$1.1+.1$

Cynanchum

vincetoxicum (L.) Pers. $+1+1$

$+1$

II

Digitalis ambigua

Murr. (Digitalis

grandiflora Miller) $\quad+.1 \quad+$.

Sedum hispanicum L.

$+1$

Campanula patula $\mathrm{L} . \quad+.1$

Myosotis arvensis (L.)

Hill

Silene italica (L.) Pers.

Acinos alpinus (L.)

Moench.

Minuartia verna (L.)

Hiern.

Myosotis sylvatica

Hoffm.

Aegopodium

podagraria $\mathrm{L}$.

$\begin{array}{ll}1.1 & +.1\end{array}$

II

Euphorbia polychroma

A. Kerner

$+.1$

$+.1+.1$

II

Euphorbia

amygdaloides $\mathrm{L}$.

$+.1$

$+.1$

$+.1$

II

Arabis procurrens

Waldst. \& Kit.

Libanotis montana

Crantz

Thymus glabrescens

Willd.

$\begin{array}{lll}+.1 & \text { - } & +2\end{array}$

Trifolium repens $\mathrm{L}$.

Carex ornithopoda

Willd.

Teucrium chamaedrys L.

Viola tricolor $\mathrm{L}$.

Clinopodium vulgare L.

$+.1$

Vicia incana Gouan.

$+.1$

$+.1$

II

Myosotis scorpioides

L.

$$
+.1
$$

$+.2$

II

Festuca valesiaca

Schleicher ex Gaudin

Viola arvensis Murray

Galium vernum Scop. 
Asplenium trichomanes

L.

Pteridium aquilinum

(L.) Kuhn

$+.1+.1$

Geranium robertianum L.

Hypericum richeri Vill.

Senecio vernalis

Waldst. \& Kit.

Scabiosa ochroleuca L.

Campanula persicifolia L.

Galium cruciata L.

Hypochoeris maculata L.

\section{Aremonia}

agrimonioides (L.) DC.

Polygala comosa

Schkuhr

Hypericum perforatum L.

Anthyllis vulneraria L.

Carex verna

Chaix.(Carex

caryophyllea Latour.)

Trifolium alpestre $\mathrm{L}$.

Polygala vulgaris L.

Medicago falcata $\mathrm{L}$.

Alyssum repens

Baumg.

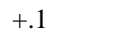

1.1

Festuca drymeja Mert.

\& Koch

Carex strigosa Hudson

Brachypodium pinnatum (L.) Beauv.

Carex pilosa Scop.

Senecio rupestris

Waldst. \& Kit.

Cerastium caespitosum Gilib.

$\begin{array}{ll}1.1 & \cdot \\ +.1 & \cdot \\ +1 & \end{array}$

Cerastium glomeratum Thuill.

Festuca varia Haenke

Legend: Degree of pr. - Degree of presence

Only in one relevé with the value of +.1 the following species were recorded:

Relevé a: Ajuga reptans L., Arabis hirsuta (L.) Scop., Avenula compressa (Heuffel) W. Sauer \& Chmelitschek, Carex halleriana Asso, Carex stellulata Good, Cerastium pumilum Curtis, Erysimum diffusum Ehrh., Ferulago sylvatica (Besser) Reichenb, Festuca xanthina Roemer \& Schultes, Geranium molle L., Koeleria gracilis Pers., Poa 
bulbosa L., Poa compressa L., Plantago lanceolata L., Potentilla cinerea Chaix ex Vill., Potentilla recta L., Primula veris L., Ranunculus bulbosus L., Reseda lutea L., Rumex acetosa L., Sanguisorba minor Scop., Scabiosa banatica Waldst. et Kit., Thesium linophyllon L.;

Relevé b: Brachypodium sylvaticum (Hudson) Beauv., Dactylis glomerata L., Fagus moesiaca (K. Maly) Czecz., Galium album Miller, Melica ciliata L., Melittis melissophyllum L., Potentilla micrantha Ramond ex DC.;

Relevé c: Asplenium ruta-muraria L., Campanula rotundifolia L., Cystopteris fragilis (L.) Bernh., Dianthus petraeus Waldst. \& Kit., Epilobium montanum L., Hypericum maculatum Crantz, Fragaria moschata Duchesne, Moehringia trinervia (L.) Clairv., Saxifraga paniculata Miller, Saxifraga rotundifolia L., Urtica dioica L., Veronica orchidea Crantz;

Relevé d: Botrichium lunaria (L.) Shwartz, Hieracium bifidum Kit., Poa trivialis L.;

Relevé e: Trifolium diffusum Ehrh., Viola sylvestris Lam.;

Relevé f: Campanula bononiensis L., Chelidonium majus L., Fragaria vesca L., Gymnadenia conopsea (L.) R. Br., Hieracium cymosum L., Hieracium bauhinii Besser, Koeleria eryostachya Pančić, Laserpitium latifolium L., Lychnis viscaria L., Ranunculus polyanthemos L., Scabiosa ucranica L.;

Relevé g: Campanula sphaerothrix Griseb., Linaria vulgaris Miller, Poa alpina L., Thymus pulegioides L.;

Relevé h: Erysimum odoratum Ehrh., Gentianella ciliata (L.) Borkh., Lathyrus vernus (L.) Bernh., Leontodon hispidus L., Medicago minima (L.) Bartal., Scrophularia nodosa L.

The stand a of locality Visoka stena was located nearby beech forest, that was not affected by fire. The number of species in the shrub layer in this relevé was increased from year to year. The first year after fire it was registered 4 (Marković, M. et al., 2018b), the second year 6 (Rakonjac, Lj. et al., 2020), and the third year 9 shrubby representatives (Table 1). The first year after fire in this stand the annual plant species Geranium dissectum was dominated with its abundance and coverage (3.3), which was assumed to be related to its short reproductive cycle (Marković, M. et al., 2018b). In the second year after the fire, there were registered significant changes in the composition of the dominant species. Annual plant species Geranium dissectum, that was dominant in the first year after the fire, the second year was replaced by perennial plants Trifolium badium (2.3) and Anthyllis vulneraria (2.2) (Rakonjac, Lj., et al., 2020). The third year after the fire, the yellow color of the inflorescences of the plant species Anthyllis vulneraria was dominated in the aspectivity of this relevé (Figure 1) with a high abundance and coverage (3.3), and the plant species Trifolium badium was disappeared. An increased abundance and coverage of perennial hamephytes has also been registered: Acinos alpinus, Helianthemum nummularium, which means that these communities were gained a more stable stage. The abundance and coverage of plant species Fragaria viridis and Silene italica were increased, in comparison with 
the second year after the fire (Rakonjac, Lj. et al., 2020), and these two species were not registered in the first year after fire (Marković, M. et al., 2018b). The second and third years of succession, a larger number of plants from the grass family was recorded: Agrostis capillaris, Poa badensis, Brachypodium sylvaticum, Avenula compressa, Festuca valesiaca. Expansion of the remnant rhizome of the grasses seems to be very important moment in succession, as the grasses are powerful colonists. Generally, achieving the "grasses stage", significantly facilitate succesion, making the vegetation recovery time shorter than it was expected.

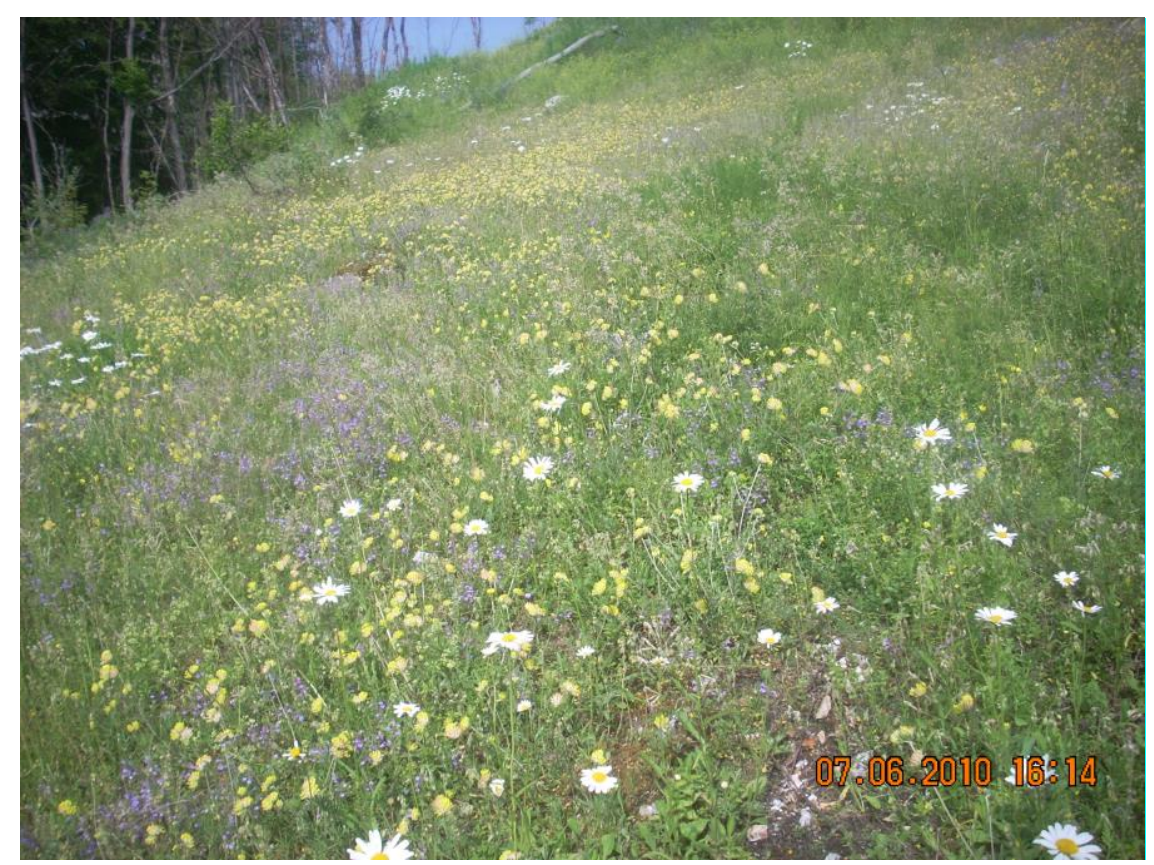

Figure 1. The aspectivity of stand $\boldsymbol{a}$ with dominance of the yellow inflorescences of plant species Anthyllis vulneraria the third year after fire at locality Visoka stena

The stand at site $\mathbf{b}$ was characterized by the fact that the beech forest was not completely burned, but only partial damage occurred. Beech trees, about $6 \mathrm{~m}$ high, were burned near the ground, and in the upper part they turned green with leaves in the first year after the fire (Marković, M. et al., 2018b). In this stand the first year after fire it was registered 8 (Marković, M. et al., 2018b), the second year 11 (Rakonjac, Lj. et al., 2020), and the third year 12 shrubby representatives (Table 1). Qualitative changes were occurred in the herbaceous layer, which refer to the composition of the species. The second year after the fire, the perennial plant Aegopodium podagraria (Figure 2) was observed (Rakonjac, Lj. et al., 2020), with increasing numbers of abundance and coverage values in the third year after the fire (from 2.2 second year to 3.4 third year). The presence of this plant species was indicated a nitrophilous and wet habitat. The second and third years after fire, a larger number of plants species Poa nemoralis from the grass family was recorded: the second and third year in comparison with the first year. Brachypodium sylvaticum from the grass family was registered the second year (Rakonjac, Lj. et 
al., 2020), and Festuca drymeia from the same family was registered the third year after fire (Table 1).

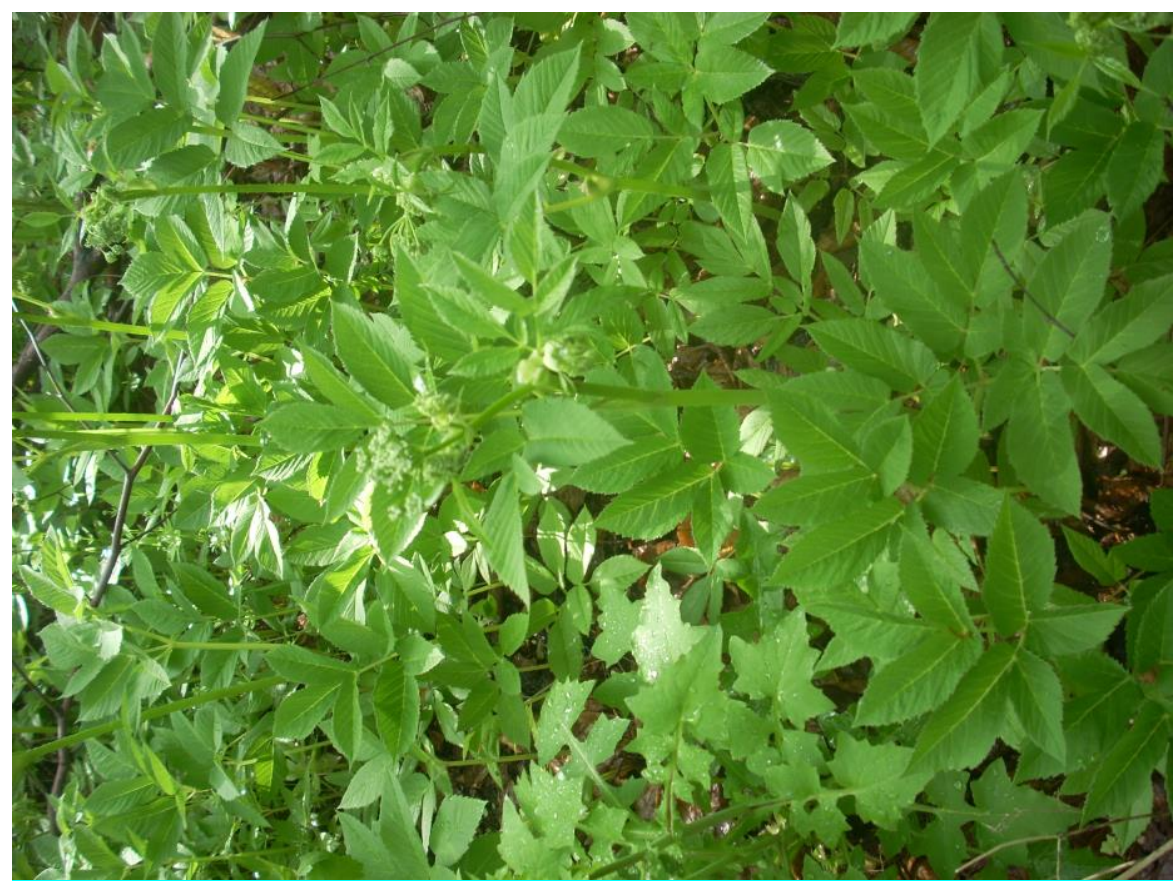

Figure 2. The perennial plant Aegopodium podagraria in the stand at site $\boldsymbol{b}$

The stand at site $\mathbf{c}$ was located at altitude of $1170 \mathrm{~m}$, with a terrain inclination of $60^{\circ}$. The abundance and coverage of the dominant shrub species Spiraea chamaedryfolia of this relevé was remained unchanged for all three years of succession monitoring (3.3). The increased numbers of abundance and coverage of shrubs Rubus idaeus and Corylus avellana, was observed, as well as herbaceous species from geranium genus: Geranium macrorrhizum and Geranium robertianum. The presence of the nitrophilous species Lamium maculatum, grass species Poa nemoralis and Epilobium angustifolium have increased.

The stand at site $\mathbf{d}$ was located at small area $(3 \times 3 \mathrm{~m})$ along a huge rock, that was look like a haystack (Figure 3 ). The species Poa nemoralis was dominated the first year after the fire with abundance and coverage of 4.4 (Marković, M. et al., 2018b), which was decreased in the second year after the fire on 2.2 (Rakonjac, Lj. et al., 2020). Qualitative changes in this relevé from year to year after fire were significant, which is indicated by the large number of species with small cover in only one year of monitoring.

The stand at site e was located nearby mentioned stands. The dominant plant species Epilobium angustifolium was with abundance and coverage 3.3, and species Lathyrus pratensis was with abundance and coverage 2.2. The common name of Epilobium angustifolium is "fireweed", that derives from the species" abundance as a colonizer on burnt sites after forest fires. 


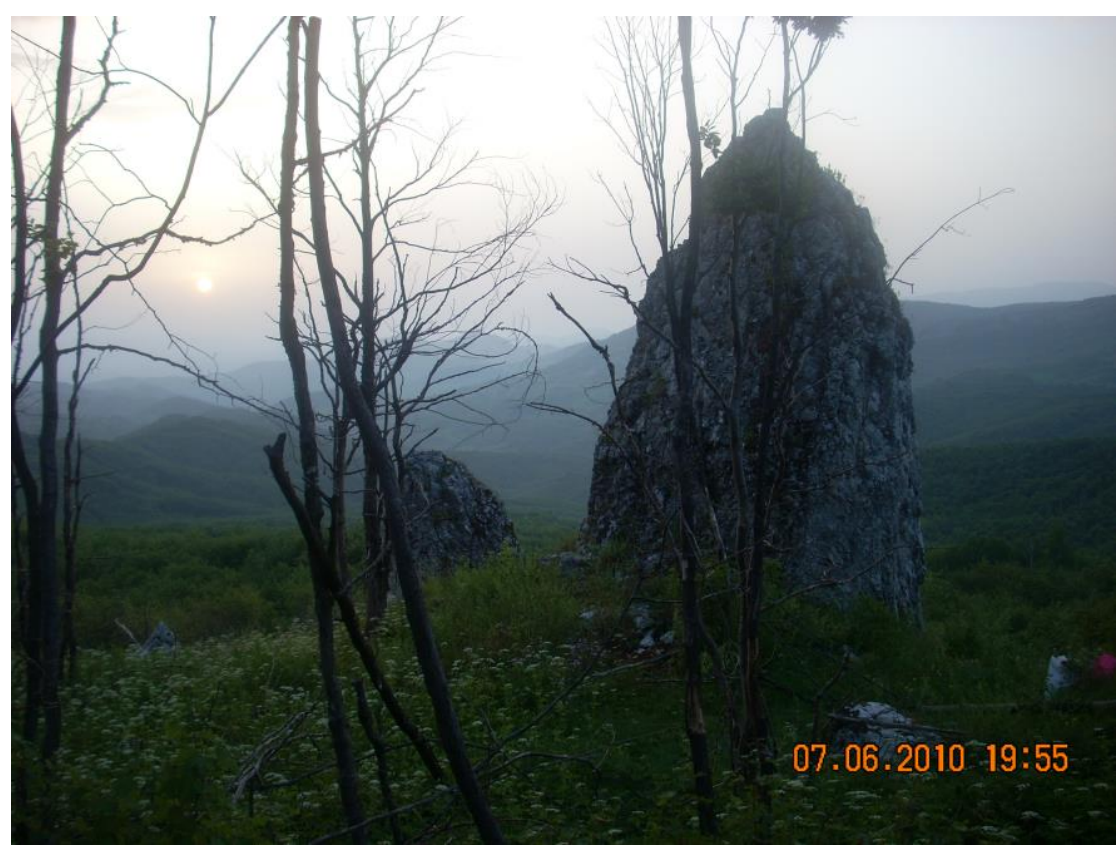

Figure 3. The stand at site $\mathbf{d}$ nearby a huge rock

The shrub species Spiraea chamaedryfolia has a slightly higher presence in the stand at locality $\mathbf{f}$. The quantitative values of coverage and abundance of this shrub were increased from year to year (Marković, M. et al., 2018b; Rakonjac, Lj. et al., 2020). The significant qualitative changes in this stand during the succession monitoring were observed. It has been noticed that different types of grass plant species were changed during the first three years after fire. The grass species Poa nemoralis and Poa compressa were recorded in the second year after the fire (Rakonjac, Lj. et al., 2020), and grass species Koeleria eriostachya the third year after fire (Table 1). The grass species Poa angustifolia was presented the second and third years after the fire, and the number of coverage and sociality increase in the third year compared to the second year after fire.

In the stand at the locality $\mathbf{g}$, the first year after the fire, the species from the grass family Poa angustifolia was dominated plant species (Marković, M. et al., 2018b). The quantitative values of coverage and abundance of this grass species were decreased in the second year after fire, while values of these parametres were increased for species: Teucrium chamaedrys and Galium mollugo (Rakonjac, Lj. et al., 2020). The species Silene italica, Myosotis sylvatica and Helianthemum nummularium not were represented in the first year after the fire (Marković, M. et al., 2018b), and they were observed in the second and third year after fire when they have a high coverage and abundance (1 or 2). Some of the herbaceous plants, which were recorded in the first year after the fire, were disappeared from this stand in the second year, and they were not registred in the third year after fire. These are mostly annual plant species: Geranium dissectum, Galium lucidum, Polygala vulgaris. Two mesophilic therophytes, Cardamine impatiens and Medicago arabica, which were not present in the first year after fire, 
were occurred in the second year after fire (Rakonjac, Lj. et al., 2020) with small numbers of coverage, and the third year they were not been recorded.

The stand at locality $\mathbf{h}$ was characterized by domination of species Epilobium angustifolium and Rubus idaeus. The first year after fire Rubus idaeus was dominated in the shrub layer (Marković, M. et al., 2018b), while the second and third year Populus tremula was dominated species. The coverage and abundance of the species Epilobium angustifolium were increased in the second and third year after the fire, compared to the first year after the fire (Rakonjac, $\mathrm{Lj}$. et al., 2020) (Table 1). In this relevé, a woody species Salix caprea has been recorded in the threes layer, and there are 8 plants in the shrub layer, which was unchanged as in the previous two monitoring seasons (Marković, M. et al., 2018b; Rakonjac, Lj. et al., 2020). New species that were recorded in the third year of succession are mostly perennial. The therophytes which were presented in the first and second year after fire were disappeared from the phytocoenological composition of the community. This means that succession was acquired a stage with domination of perennials. They can create the conditions and prepare the ground for other plants, especially vegetative shoots of woody plants Populus tremula and Salix caprea from the shrub layer, to move through a few years from shrub layer to threes layer and form a pioneer forest. The beech saplings can be formed and developed in shadows of their crowns, which, with are the good starting point for natural regeneration of beech forest.

In Table 2 orographic data and diversity at beech forest fires at the locality Visoka stena the third year after fire (2010), as well as the previous two seasons are presented. The highest diversity was shown by stand a (0.983), and the lowest diversity of stands e (0.959).

Table 2. Orographic data in the areas of beech forest affected by fire at locality Visoka stena, species richness and alpha diversity by Whitaker, R.H. (1972), in the first - 2008 (Marković, M. et al., 2018b), second-2009 (Rakonjac, Lj. et al., 2020), and third - 2010 year after fire on Vidlič Mountain

\begin{tabular}{|l|c|c|c|c|c|c|c|c|c|}
\hline Relevé & $\begin{array}{c}\text { Altitude } \\
(\mathbf{m})\end{array}$ & Exposure & $\begin{array}{c}\text { Terrain } \\
\text { inclination } \\
\left({ }^{\circ}\right)\end{array}$ & $\begin{array}{c}\text { Species } \\
\text { richness } \\
\mathbf{2 0 0 8}\end{array}$ & $\begin{array}{c}\text { Diversity } \\
\text { index } \\
\mathbf{2 0 0 8 .}\end{array}$ & $\begin{array}{c}\text { Species } \\
\text { richness } \\
\mathbf{2 0 0 9}\end{array}$ & $\begin{array}{c}\text { Diversity } \\
\text { index } \\
\mathbf{2 0 0 9} .\end{array}$ & $\begin{array}{c}\text { Species } \\
\text { richness } \\
\mathbf{2 0 1 0 .}\end{array}$ & $\begin{array}{c}\text { Diversity } \\
\text { index } \\
\mathbf{2 0 1 0 .}\end{array}$ \\
\hline $\mathbf{a}$ & 1115 & $\mathrm{~W}$ & 70 & 49 & 0.977 & 66 & 0.983 & 69 & 0.983 \\
\hline $\mathbf{b}$ & 1150 & $\mathrm{NW}$ & 5 & 50 & 0.978 & 47 & 0.977 & 47 & 0.975 \\
\hline $\mathbf{c}$ & 1170 & $\mathrm{~N}$ & 60 & 35 & 0.967 & 46 & 0.975 & 48 & 0.977 \\
\hline $\mathbf{d}$ & 1140 & $\mathrm{NW}$ & 20 & 14 & 0.903 & 36 & 0.970 & 33 & 0.966 \\
\hline $\mathbf{e}$ & 1135 & $\mathrm{~N}$ & 30 & 23 & 0.953 & 22 & 0.945 & 29 & 0.959 \\
\hline $\mathbf{f}$ & 1130 & $\mathrm{NE}$ & 60 & 24 & 0.957 & 53 & 0.979 & 51 & 0.978 \\
\hline $\mathbf{g}$ & 1050 & $\mathrm{NW}$ & 40 & 56 & 0.980 & 69 & 0.984 & 46 & 0.974 \\
\hline $\mathbf{h}$ & 1050 & $\mathrm{NW}$ & 30 & 29 & 0.962 & 34 & 0.964 & 37 & 0.968 \\
\hline $\mathbf{i}$ & 1100 & $\mathrm{SW}$ & 30 & - & - & 42 & 0.974 & - & - \\
\hline
\end{tabular}

The average value of diversity in the first year after the fire was 0.959 , in the second year was 0.972 , and in the third year was 0.973 . The second and third year after fire, diversity was increased compared to the first year, so that communities were more stable. Increasing diversity year after year after the fire demonstrates intense process of species immigration from surounding unburned vegetation via empty sites of burned plots. 
The third year after the fire at locality Visoka Stena of the Vidlič Mountain, the increased number of shrubs was registred. There are more favorable conditions for survival and further development of beech seedlings in their shadows. It is a good precondition for gradual natural regeneration of beech forest. Favorable soil conditions can also contribute to the successful germination of seeds and the development of beech saplings on the surface area after the fire. By burning a thick layer of dry leaves during the fire, it is possible for beech seeds to fall directly on the soil, that is richer in nutrients than before the fire. Reduced amount of undecomposed organic matter and increased insolation affect more favorable aeration conditions, as well as an increase in bacteria (Vukićević, E., 1965). These are the good conditions for germination and development of beech saplings. Except from seeds, beech can well regenerated on fire affected habitats vegetatively. Many trees, which were damaged by fire in the stand at site $b$, can give good shoots from stumps.

\section{CONCLUSION}

The third year after wildfire at locality Visoka stena on the Vidlič Mountain was characterized by an increase in the number of perennial plants. Bunch grasses and other perennial species became dominant. As expected, sparse members of phanerophytes in the threes and shrub layer, remained fire nonaffected; while some of them additionally increased in the third year after fire. In their shadows, better conditions were created for the development of beech seedlings. More favorable soil conditions, which are richer in nutrients than before the fire, also contribute to the development of beech saplings. After the initial fall, diversity generally increases in almost all burned sites in comparation to the previous seasons, so that the formed stands are more stable. They represent transitional stages in the process of reforestation of beech forest.

Further monitoring of the floristic composition and structure of the beech forests and phytocoenological characteristics of the described stands is necessary, especially at the cites which were completely burned in the wildfire, as well as the analysis of the diversity of beech forests damaged by wildfires. The aim of further monitoring can be to establish the stages in the process of spontaneous natural regeneration of the beech forests after wildfires in Serbia.

\section{REFERENCES}

Braun-Blanquet, J. (1964): Pflanzensoziologie, Grundzüge der Vegetationskunde. (Berlin, itd: Spiringet: Verlag).

Certini, G., 2005. Effects of fire on properties of forest soils: a review. Oecologia 143: 110.

Josifović, M. (Editor) (1970-1986): Flora of SR Serbia I-X, Serbian Academy of Sciences and Arts, Belgrade. (In Serbian).

Kamilovski, M. (1965): Conditions that increase the possibility of forest fires, Šumarski list 1-2, 64-70. (In Croatian). 
Karadžić, B., V. Šošo-Jovanović, Z. Jovanović, and R. Popović. (1998): "Flora" a database and software for floristic and vegetation analyzis. In: Tsekos I. and $\mathrm{M}$. Moustakas (eds.) Progress in Botanical Research. Kluwer Academic Press, Dodrecht, pp. $69-72$

Marković, S.M., Nikolić, M.B., Zlatković, K.B., Nikolić, S.D., Rakonjac, B.Lj., StankovJovanović, P.V., Djokić, M.M., Ratknić, B.M., Lučić, Ž.A. (2018a): Short-term patterns in the post-fire diversity of limestone grasslands and rocky ground vegetation, Applied Ecology and Environmental Research 16(3): 3271-3288.

Marković, M., Rakonjac, Lj., Nikolić, B., Lučić, A., Đelić, G. (2018b): Beech forest affected by fire at locality Visoka stena the first year after fire on the Vidlič mountain, Pirotski zbornik 43, 165-180. (In Serbian).

Nikolov, N. (2015): Forest Fires Country Study, Republic of Serbia. In: Nemeth, A. (ed.) Regional Environmental Center for Central and Eastern Europe, Serbia.

Panić, M. (2007): The program of rehabilitation and restoration of postfire areas. No. 093405, Date: 06.08.2007. "Serbia Forests”, Pirot, Serbia. (In Serbian).

Petrović, N. (1956): On factors which exert an influence upon the intensity and behaviour of forest fires. Forestry, Belgrade IX(3): 157-162. (In Serbian).

Petrović, N. (1965): Influence of low fire temperature on living trees in pure beech stands. Doctoral dissertation. Belgrade, University of Belgrade, Faculty of Forestry. (In Serbian).

Rakonjac, Lj., Marković, M., Nikolić, B., Lučić, A., Ratknić, T. (2018): Floristic composition of oak forests and Oriental hornbeam scrubs on Mt. Vidlič in the first three years after a wildfire Sustainable forestry, Collection 77-78, 2018, pp. 11-28.

Rakonjac, Lj., Nikolić, B., Marković, M. Ratknić, T., Lučić, A. (2020): Burnt down beech wood area at the location of Visoka Stena second year after the fire on Vidlič mountain, Pirotski zbornik 45, 65-79. (In Serbian).

Ratknić, M., Rakonjac, Lj., Matović, M., Bilibajkić, S., Braunović, S. (2006): Development of an expert system for forest fire protection in Tara National Park. International Scientific Conference Management of Forest Ecosystems of National Parks and Other Protected Areas: Proceedings (pp. 381-388). Banja Luka, Faculty of Forestry.

Tabaković-Tošić, M., Marković, M., Rajković, S., Veselinović, M. (2009): Wildfires in Serbia-Chance or frequent phenomenon, Sustainable Forestry, Collection 59-60, Institute of Forestry, Belgrade, 97-125.

Tutin, T.G., Heywood, W.H., Burges, N.A., Moore, D.M., Valentine, D.H., Walters, S.M., Webb, D.A. (1964-1980): (Eds), Flora Europaea, I-V. Cambrige University Press. London.

Tutin, T.G., Burges, N.A., Chater, O.A., Edmondson, J.R., Heywood, V.H., Moore, D.M., Valentine, D.H., Walters, S.M., Webb, D.A. (1993): (Eds.), Flora Europaea 1 (2nd Edition). Cambridge University Press, London. 
Velkovski, N., Acevski, J., Vasilevski, K., Simovski, B. (2012): Rehabilitation of burnest forest ecosystems by natural regeneration, 4th Congress of ecologists of the Republic Macedonia with international participation, Ohrid, Macedonia, 12-15 October, 2012. Abstract book: 23 .

Vukićević, E. (1965): Succession of Vegetation and Natural Regeneration of Forests in Serbia, Dissertation, Faculty of Forestry, University of Belgrade (Serbia). (In Serbian).

Whitaker, R.H. (1972): Evolution and measurement of species diversity, Taxon 21 (2\3): 213-251.

\title{
PHYTOCOENOLOGICAL CHARACTERISTICS OF BEECH FORESTS AT LOCALITY VISOKA STENA THE THIRD YEAR AFTER THE WILDFIRE ON VIDLIČ MOUNTAIN
}

\author{
Ljubinko RAKONJAC, Marija MARKOVIĆ, Biljana NIKOLIĆ, \\ Aleksandar LUĆIĆ, Tatjana RATKNIĆ
}

\section{Summary}

The paper presents the phytocenological characteristics of burned beech forests in the third year after the fire at locality Visoka Stena on the Vidlič Mountain. The obtained results were compared with the floristic composition of the previous two seasons at the same locality.

An increase in plants from the grass family was noticed in the stand on the site a and in the immediate vicinity of the unburned beech forest, which is a very important moment in the succession, because the grasses are powerful colonists. In the same stand, there is an increase in the number of shrubby representatives in relation to the previous two seasons, in which shadows the conditions for the development of beech seedlings, can be expected in the following years.

In the stand on the site $\mathbf{b}$, in which the beech forest has not completely burned down, but only partial damage has occurred, the appearance of new beech shoots from stumps is expected.

In the stand on the site c, the dominant shrub species Spiraea chamaedryfolia retained unchanged abundance and coverage for all three years of succession monitoring (3.3). However, an increase in the abundance and coverage of shrub species was observed: Rubus idaeus and Corylus avellana, as well as a larger number of herbaceous representatives.

In the stand on the site $\mathbf{d}$, the qualitative changes from year to year are significant, which is indicated by the large number of species with a small number and cover only in one year of succession monitoring.

In the stands on the site $\mathbf{e}$, the dominant plant species Epilobium angustifolium was with abundance and coverage 3.3, and species Lathyrus pratensis was with abundance and coverage 2.2 .

In the stand on the site $\mathbf{f}$, it was noticed that different types of grasses alternate in the process of succession. The species Koeleria eriostachya was recorded in the third year after the fire, the species Poa angustifolia was present in the second and third year after the fire, and its abundance and coverage increased in the third year after fire in comparison with the second year of succession monitoring.

In the stand on the site $\mathbf{g}$, some of the herbaceous plants that were recorded in the first year after the fire were disappeared from the stand in the second year, and there were 
not noticed none in the third year of succession. These were mainly annual plants (Geranium dissectum, Galium lucidum, Polygala vulgaris).

The stand on the site $\mathbf{h}$ were dominated by perennials, which further prepare the ground for other plants, especially vegetative shoots of woody plants Populus tremula and Salix caprea from the shrub layer, so that in the further process of succession they move from shrub layer to threes layer. They can influence the conditions in which the formation of young beech forest is expected.

There was a quantitative increase in the mean value of the Simpson diversity index (0.973) compared to the first (0.959) and second year (0.972) after the fire. The increase of diversity reflects the more intensive process of species immigration from neighboring unburned areas. Increasing the number of woody and shrubby representatives can enable the survival and further development of beech seedlings in their shadows. Favorable soil conditions also contribute to the favorable germination and development of beech saplings. It is richer in nutrients than before the fire.

\title{
FITOCENOLOŠKE KARAKTERISTIKE BUKOVIH ŠUMA NA LOKALITETU VISOKA STENA TREĆE GODINE POSLE POŽARA NA PLANINI VIDLIČ
}

\author{
Ljubinko RAKONJAC, Marija MARKOVIĆ, Biljana NIKOLIĆ, \\ Aleksandar LUČIĆ, Tatjana RATKNIĆ
}

\section{Rezime}

U radu su prikazane fitocenološke karakteristike opožarenih bukovih šuma treće godine posle požara na lokalitetu Visoka Stena na planini Vidlič. Dobijeni rezultati su upoređeni sa florističkim sastavom prethodne dve sezone na istom lokalitetu.

U sastojini na lokalitetu a u neposrednoj blizini neopožarene bukove šume zabeleženo je povećanje biljaka iz porodice trava, što predstavlja veoma važan trenutak u sukcesiji, jer su trave moćni kolonisti. U istoj sastojini dolazi do povećenja broja žbunastih predstavnika u odnosu na prethodne dve sezone, u čijim se senkama stiču uslovi za razvoj bukovih klijanaca, čije prisustvo nije zabeleženo, ali se očekuje narednih godina praćenja.

U sastojini na lokalitetu b, u kojoj bukova šuma nije u potpunosti izgorela, već je došlo samo do delimičnog oštećenja, očekuje se pojava novih bukovih izdanake iz panjeva.

U sastojini na lokalitetu c dominantna žbunasta vrsta Spiraea chamaedryfolia zadržala je nepromenjenu brojnost i pokrovnost sve tri godine praćenja sukcesije (3.3). Međutim, zapaženo je povećanje brojnosti, pokrovnosti i socijalnosti žbunastih vrsta: Rubus idaeus i Corylus avellana, kao i većeg broja zeljastih predstavnika.

U sastojina na lokalitetu d kvalitativne promene iz godine u godinu su znatne, na šta ukazuje veliki broj vrsta sa malom brojnošću i pokrovnošću samo u po jednoj godini praćenja sukcesije.

U sastojini na lokalitetu e dominira biljna vrsta Epilobium angustifolium sa brojnošću i pokrovnošću 3.3, kao i vrsta Lathyrus pratensis sa brojnošću i pokrovnošću 2.2.

U sastojini na lokalitetu f $\mathbf{f}$ zapaženo je da se u procesu sukcesije smenjuju različite vrste trava. Vrsta Koeleria eriostachya zabeležena je treće godine posle požara, vrsta Poa angustifolia je prisutna druge i treće godine nakon požara, a brojnost i pokrovnost se povećavaju treće u odnosu na drugu godinu praćenja sukcesije.

U sastojini na lokalitetu $\mathbf{g}$ neke od zeljastih biljaka koje su zabeležene prve godine posle požara nestaju iz sastojine već druge godine, a nema ih ni treće godine sukcesije. To su uglavnom jednogodišnje biljke (Geranium dissectum, Galium lucidum, Polygala vulgaris). 
Sastojina na lokalitetu h sukcesija zadobija stadijum sa dominacijom višegodišnjih biljaka, koje dalje pripremaju teren drugim biljkama, a pogotovo vegetativnim izbojcima drvenastih biljaka Populus tremula i Salix caprea iz sprata žbunova, kako bi u daljem procesu sukcesije prešle iz sprata žbunova u sprat drveća. Oni mogu stvoriti uslove u kojima se očekuje razvitak mlade bukove šume.

Zabeleženo je kvantitativno povećanje srednje vrednosti Simpsonovog indeksa diverziteta (0.973) u poređenju sa prvom (0.959) i drugom godinom (0.972) posle požara. Povećanje diverziteta odražava intenzivniji proces imigracije vrsta sa susednih neopožarenih površina. Povećanje broja drvenastih i žbunastih predstavnika može da omogući opstanak i dalji razvoj bukovih klijanaca u njihovoj senci. Povoljnom klijanju i razvoju bukovog podmladka doprinose i povoljni uslovi zemljišta. Ono je bogatije hranljivim elementima nego pre požara. 